\title{
EFFECTS OF SPORT TOURISM ON TEMPERATE GRASSLAND COMMUNITIES (DUNA-IPOLY NATIONAL PARK, HUNGARY)
}

\author{
DOBAY, G. ${ }^{* 1}$ - DOBAY, B. ${ }^{2}$-S.-FALUSI, E. ${ }^{1}-$ HAJNÁCZKI, S. ${ }^{1}-$ PENKSZA, K. ${ }^{1}-$ BAJOR, Z. ${ }^{1}-$ \\ LAMPERT, R. ${ }^{1}$ - BAKÓ, G. ${ }^{1}$ - WICHMANN, B. ${ }^{1}$-SZERDAHELYI, T. ${ }^{1}$ \\ ${ }^{1}$ Szent István University, Institute of Botany and Ecophysiology \\ ${ }^{2}$ Selye János University, Department of Physical Education \\ H-2103 Gödöllö, Páter K. u. 1 . \\ (phone: +36-28-522-000/1668; fax: +36-28-410-804) \\ *Corresponding author \\ e-mail: Dobay.Gergely@gmail.com \\ (Received 12 $2^{\text {th }}$ Jul 2014; accepted $14^{\text {th }}$ Jul 2016)
}

\begin{abstract}
Effects of sport tourism were examined in dry grassland stands with fix sample plots in four sites of strictly protected areas of Buda Mountains and Pilis in Duna-Ipoly National Park in the vicinity of Budapest (Hungary). The size of all sample plots was $2 \times 2 \mathrm{~m}$ in all sites, we designated $4 \times 10$ sampling quadrats and $4 \times 10$ control quadrats. The date of surveying was in May and July in 2013 . The sampling sites were exposed to different type of illegal sport activities. The questions we tried to answer were which changes were caused by different sport activities, is the nature protection work in the surveyed areas effective enough. Data of sample and control plots were analyzed by multivariate analyses. The species composition of parallel plots of samples and controls were compared with their ecological parameters. According to the results of cluster analysis and redundancy analysis, the composition of species of the sample plots deviated from the control plots and the difference between them were at Pilis site the most considerable. In the sample plots the rate of uncovered soil surface was meaningful and the stony surface and the leaf litter cover were higher there than in the control plots. At the sample plots the distribution of social behaviour categories showed higher ratio in the categories of generalists, ruderal competitors and weeds, while the ratio in the categories of natural competitors and specialists decreased there. At the sample plots the life forms categories showed higher ratio in the categories of therophytes and chamaephytes than at the control plots.
\end{abstract}

Keywords: degradation, sport tourism, grassland, nature conservation, coenology

\section{Introduction}

According to researchers the main topic in leisure science is the sport tourism, which is developing the most dynamically in the sector of the tourism (Murphy, 1985; Edginton and Chen, 2009; Bánhidi, 2012; Leber, 2012). Sport touristic researches started first abroad in the 80's (Turco et al., 2002). The model of phenomenon of sport tourism was described by Turco who said that the natural habitats and sport activities are interacting. On the base of this model several researchers dealt with these interactions of natural habitats and sport tourism (Dobay and Bánhidi, 2009). The concept of 'natural habitats' was used like an essential condition of sport activities examined by this approach. The increasing popularity of outdoor sport activities will probably increase their impact on natural habitats too. Due to this we think that examinations of effects of active sport tourism will become increasingly important.

Temperate grasslands cover large areas of the Earth's vegetation (Coupland, 1992), and they are typical in the regions where the impact of global climate change is predicted to be high (Campbell et al., 2000; Deák et al., 2014; Valkó et al., 2014). The temperate grassland surface has large and increasing areas with arid climate. Even in the 
middle of Europe, Hungary has wide variety of temperate grasslands from nutrient-rich loess grasslands to temperate semidesert sand grasslands (Tóth and Hüse, 2014; Albert et al., 2014) in areas where the relatively low and unevenly distributed yearly precipitation results in temperate semidesert conditions (Fekete et al., 1988; Zólyomi and Fekete, 1994). The open and closed grasslands, cliff vegetation are important elements of the original vegetation of Hungary. Various communities developed on the different bedrocks in the Carpathian Basin after the last glacial period. Due to the former climate changes differences were realized in floristic composition, since these mountain grasslands acted as refugia for many species by providing special microclimate. The grassland stands of strictly protected areas of Duna-Ipoly Natural Park are really valuable and remarkable communities in the Carpathian Basin, but these stands are exposed to a high pressure of tourism because of their vicinity to Budapest. There is a wide range of sport activities done illegally in these sites: off trail hiking, mountain biking, motocross, riding ATVs, horse riding and paragliding.

We explain the changes of grassland stands in the study sites using fixed plots. We have set the objective to look for the answer to the question which effects cause sport activities in the surveyed areas.

\section{Material and methods}

The examined four sites are under the competence of the Duna-Ipoly National Park Directorate and were the following: 1st site was on the southwest slope of Sas-hegy (GPS coordinates: sample plots N47 28,551 E019 1,122 control plots: N47 28,549 E019 1,120), the 2nd site was on the Szállás-hegy close to Csiki-hegyek (GPS coordinates: sample plots N47 28,202 E018 55,569 control plots: N47 28,201 E018 55,572), the 3rd site was on the Kutya-hegy (GPS coordinates: sample plots N47 35,317 E018 50,337 control plots: N47 35,448 E018 50,623) and the 4th site was on the Pilis (GPS coordinates: sample plots N47 41,127 E018 52,263 control: N47 41,129 E018 52,267). The species richness of the open and closed grassland called our attention to the stands of Cleistogeni-Festucetum sulcatae (Zólyomi, 1958) association. The size of all sample plots was $2 \times 2 \mathrm{~m}$ in all sites. The date of surveying was in May and July in 2013. The relative ecological parameters of the species composition detected of all sample plots were following ones: social behaviour types and life form categories. For statistical evaluation the ecological characters of species were collected from Hungarian Database 1.2 (Horváth et al., 1995). The values of ecological indicator numbers of species (Borhidi, 1995) were given in percentage pro rata.

The species composition of the sample plots was subjected to cluster analysis, using SYN-TAX 5.0 program with percentage differences-index (Podani, 1993, 1994) trying to explain the coenological meaning of the formed groups. A hierarchic (cluster) analysis was performed. To explain more the difference between the species composition of plots we used a constrained ordination method to make ordination diagrams. For the redundancy analysis (RDA) we used CANOCO 5 software (Šmilauer and Lepš, 2014). 


\section{Results and discussion}

\section{The Sas-hegy site}

In the centre of the capital city, there is an intact dolomite hill with several valuable, endemic and rare plants of the Carpathian Basin. This site is a popular tourist attraction due to the view. Tourists often leave the trail and even camp there at night. To avoid these activities, the management of the Sas-hegy Nature Reserve mounted surveillance cameras and hired a night guard. Below the top of Sas-hegy, on the southwest slope our fixed transects were located cca. $10 \mathrm{~m}$ from each other. The sample and control plots had $30^{\circ}$ degrees of slope. In the dendrogram at $\mathrm{D}=56$ dissimilarity value we have 5 groups (Fig. 1). In the 1st group $(1,2,8,3$, 13) the following species are present: Artemisia alba, Asperula cynanchica, Bothriochloa ischaemum, Euphorbia cyparissias, Festuca valesiaca, Minuartia setacea, Potentilla arenaria, Sanguisorba minor, Stipa joannis and Thymus pannonicus. The 2nd group $(12,14,15,17,16,18,20)$ is corporated from control plots with the presence of the following species: Asperula cynanchica, Galium glaucum, Euphorbia cyparissias, Linaria angustissima, Sanguisorba minor, Silene conica and Stipa joannis. The 20th plot is in connection with the others only with presence of Chrysopogon gryllus. The 3rd group with a single plot (11) is characterised by the highest cover value of leaf litter. The plots of 4th group are in the vicinity of other parts of the sample plots $(4,5,6,7,9,10)$. In the 4th group the higher cover value of Euphorbia seguieriana and the presence of Scorzonera hispanica are characteristic. The last group (5th) has only one plot with the presence of Lithospermum arvense, Stipa capillata and Allium scorodoprasum.

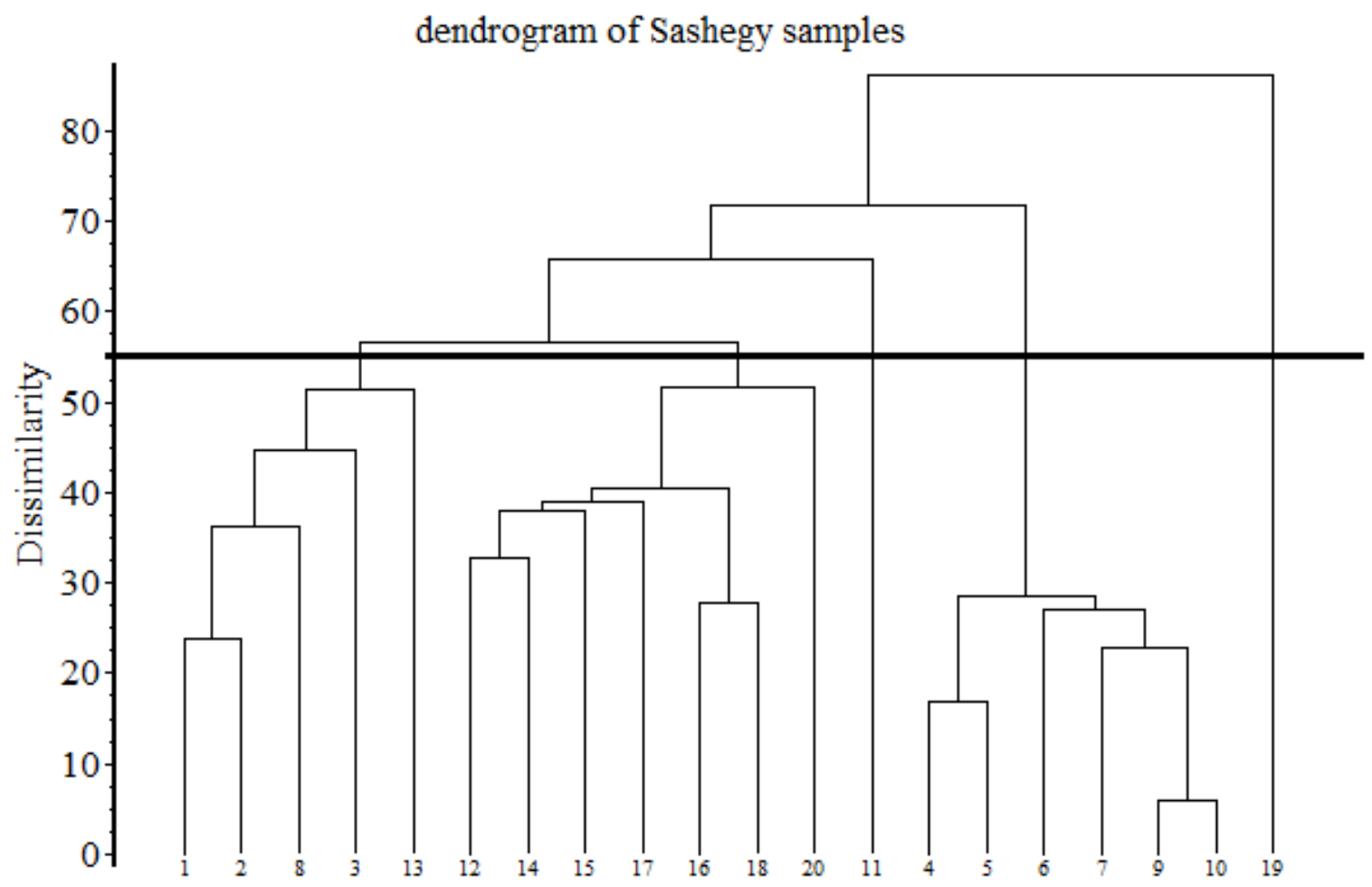

Figure 1. Dendrogram of the sample (1-10) and control (11-20) plots of Sas-hegy 
The distribution of life form categories shows more hemikryptophytes and chamaephytes in the sample plots than in the control plots.

The highest difference is in the category of therophytes, the ratio of therophytes in the control plots is significant (Fig. 2).

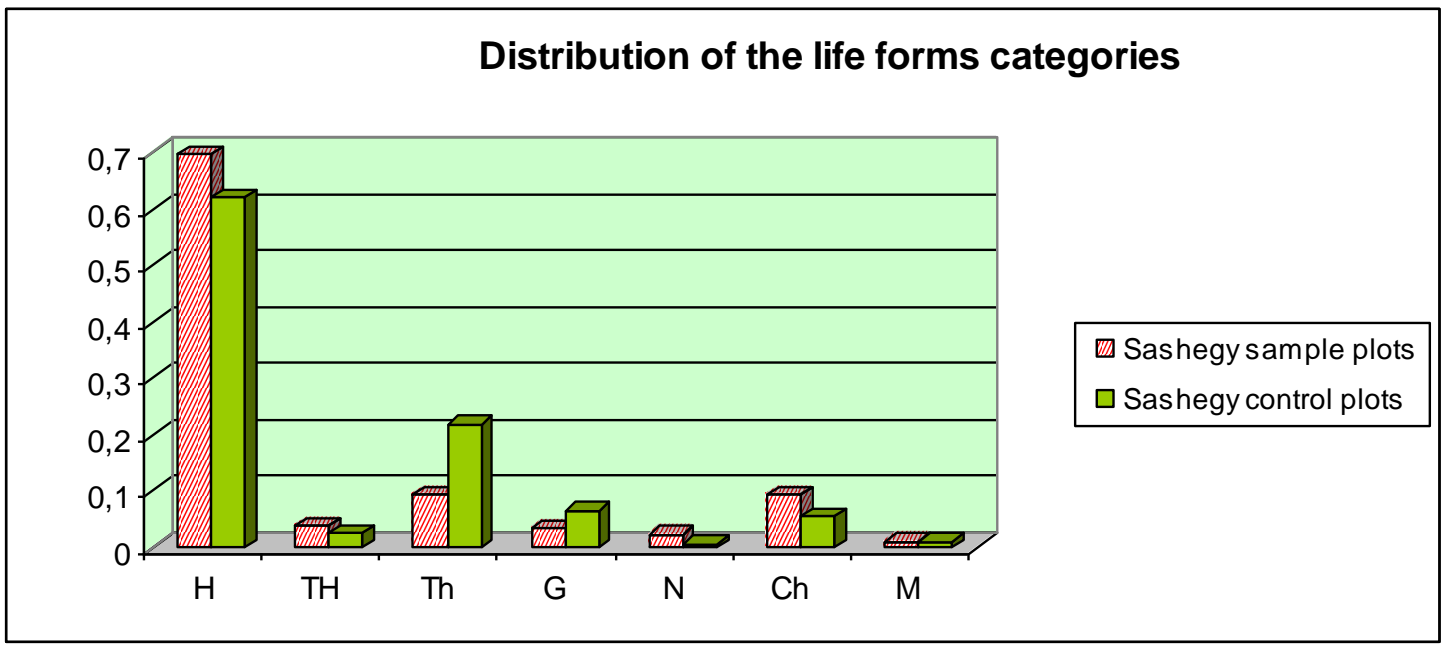

Figure 2. Distribution of the life form categories of the sample and control plots of Sas-hegy

The distribution of social behaviour types shows that generalists and stress tolerators are present in the greatest proportion in the sample plots. The ratio of natural pioneer species and specialists is lower in the sample plots than in the control plots (Fig. 3).

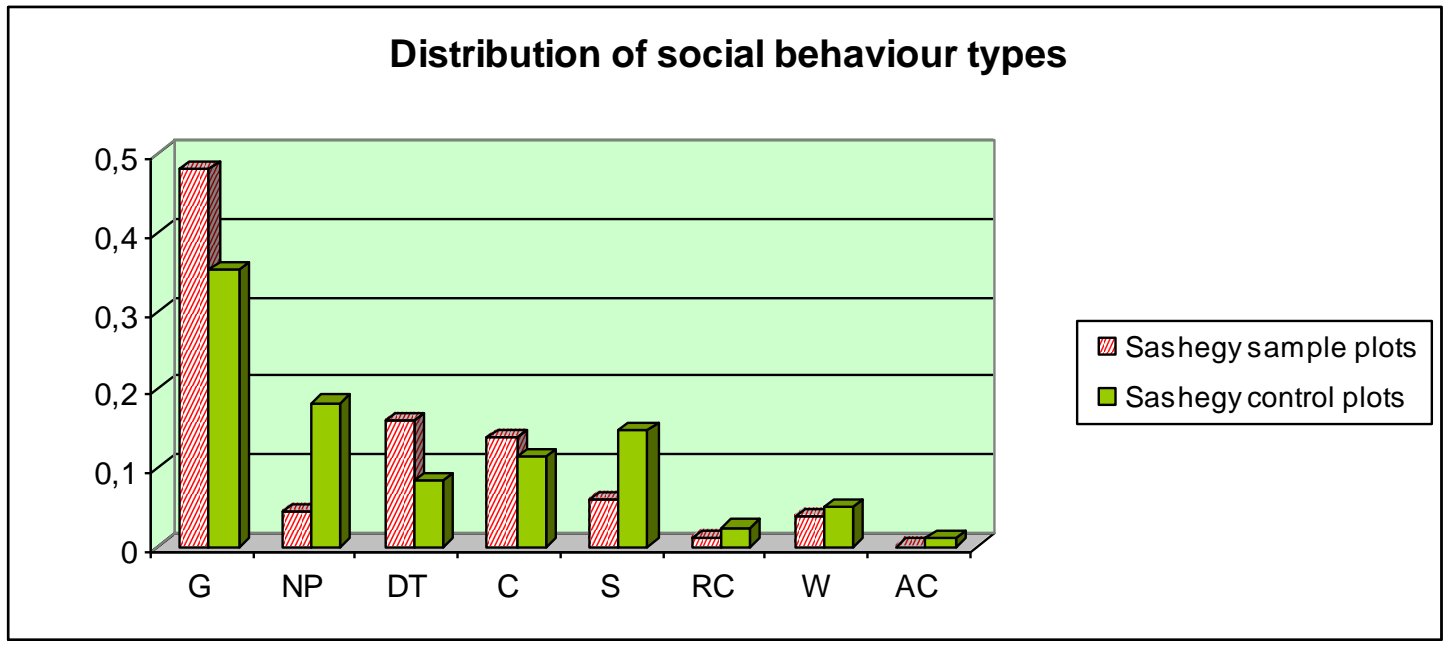

Figure 3. Distribution of the social behaviour types of the sample and control plots of Sas-hegy

The ordination diagram (Fig. 4) shows that the disturbed (D) and the control (C) plots are not forming two uniform groups according to the species composition. C1 plot is more similar to the disturbed ones; D9 and D10 are closer to the control plots than to the disturbed ones. 


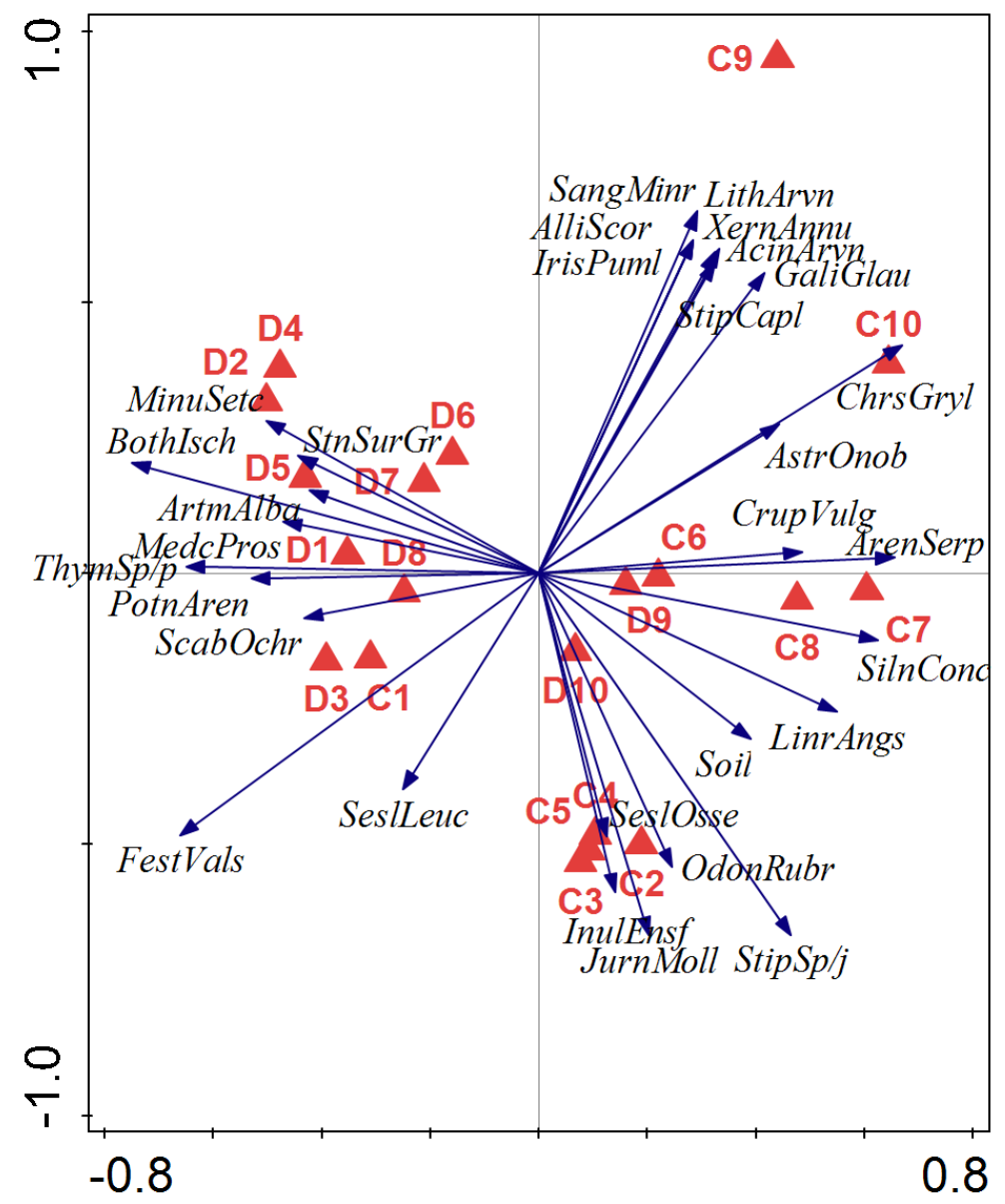

Figure 4. RDA ordination diagram of plots of Sas-hegy (D-distrubed, C-control)

\section{The Szállás-hegy site}

Szállás-hegy is a part of the ridge of the Csiki-hegyek, which is the southern part of Buda Mountains. The study area belongs to the Buda Protected Landscape Area. Despite strict protection, this area is traversed by more tourist paths. The biggest problems are caused by mountain bikers and motocross, because the thin soil layer of the dolomite surface is being snatched off. After damaging the plant cover, soil erosion starts quickly. The regeneration is nearly impossible on the thin soil and moving dolomite gravel. Despite the obligation of permission to visit this strictly protected area, we frequently met illegal bikers, off trail hikers, motocross and ATV riders close to our sample plots. There is no retentiveness of warning signs and traverses. The control plots were placed cca. $4 \mathrm{~m}$ from disturbed transect. In this area the grass layer was not disturbed but coherent.

In the trod area chosen a motocross-mountain biker path was clearly recognizable. 10 samples of $2 \times 2 \mathrm{~m}$ plots were taken in this disturbed area (trod area) in a line transect form and 10 samples of $2 \times 2 \mathrm{~m}$ plots of other transect was the control area without disturbance. (July of 2013, arranged in horizontally and parallel position).

The dendrogram of the two sample plots (disturbed and control areas) at $\mathrm{D}=35$ dissimilarity value form 4 groups and one sample is strictly separate from the others 
(Fig. 5). The similar species composition and the mass of Festuca rupicola and Inula ensifolia bind the 1st and 2nd samples forming the first group.

The second group is composed from two parts. The first part consists control samples and the 8th and 9th sample plots. These plots are similar to control plots partly because of species composition, by the presence of Anthyllis vulneraria, Centaurea sadleriana, Euphorbia cyparissias, Linaria angustissima, Muscari neglecta, Onosma arenarium, Plantago lanceolata, Teucrium chamaedrys and Thalictrum pseudominus and the lack of Euphorbia seguieriana, Fumana procumbens, Minuartia setacea, Potentilla arenaria and Scorzonera hispanica, high rate of leaf litter and low rate of uncovered soil surface. The 8-9th and 12-14th plots are different from the other groups (15-20) with low cover of Carex humilis and Teucrium chamaedrys and high cover of bare soil surface. The 7th and 11th plots are similar to each other in the high cover values of Stipa pennata and form a separate group. The last group consists 3rd, 4th, 5th and 10th disturbed sample plots because of the presence of Ajuga laxmannii, Alyssum montanum, Asperula cynanchica species and the high cover of bare soil surface. In the degraded plots the cover of bare soil surface is higher than in the others. So the cover values are much smaller in degraded plots than the control ones. The cover values of Carex humilis are higher in the control plots than in degraded plots. These results are likely caused by the dry summer of 2013 and partly 2012. In Szállás-hegy site, the dry weather was likely a stronger factor than the erosive and/or disturbance processes in 2013.

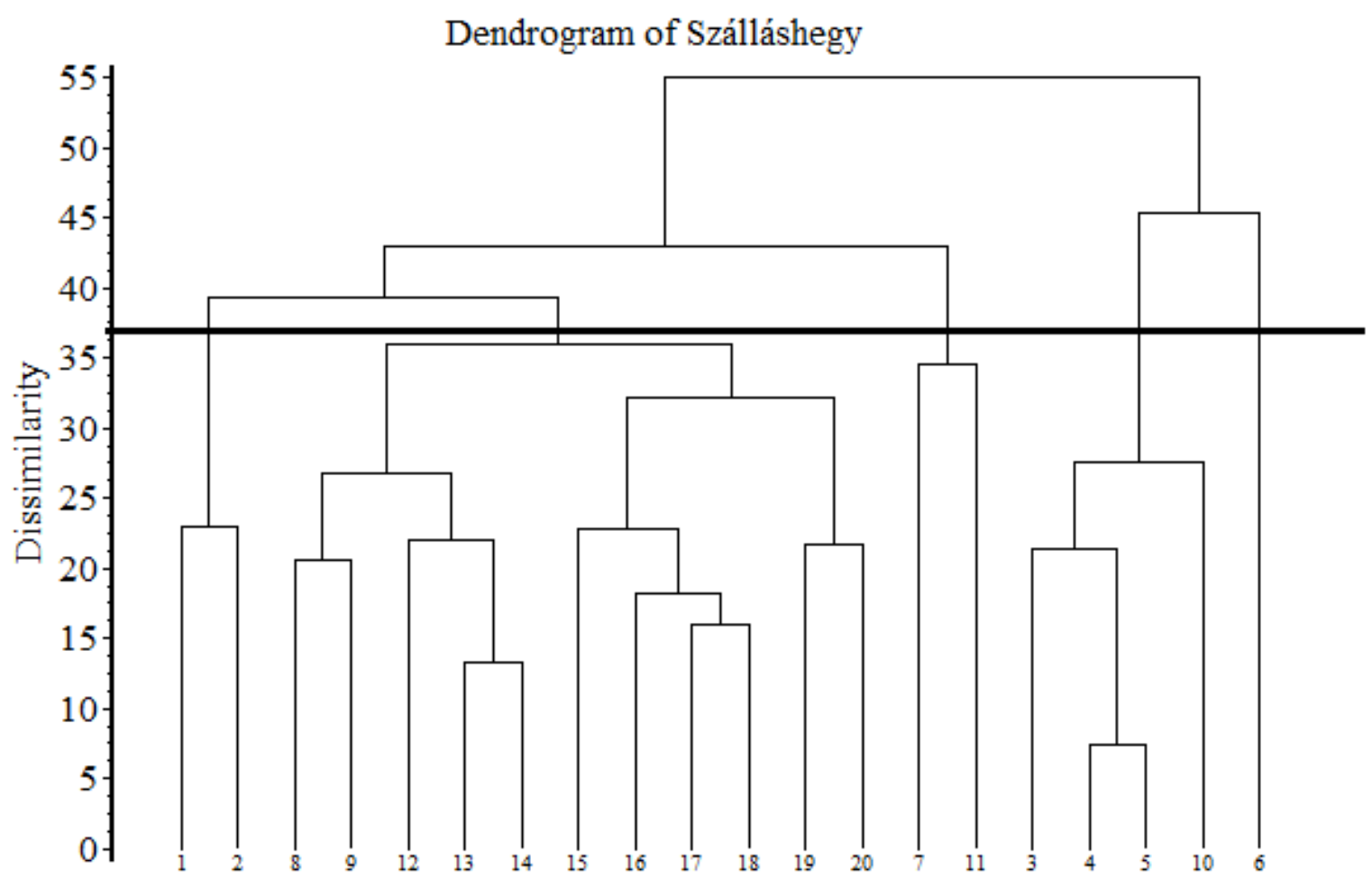

Figure 5. Dendrogram of the sample (1-10) and control (11-20) plots of Szállás-hegy 
The distribution of life form categories doesn't show any significant difference between the sample plots and the control plots (Fig. 6).

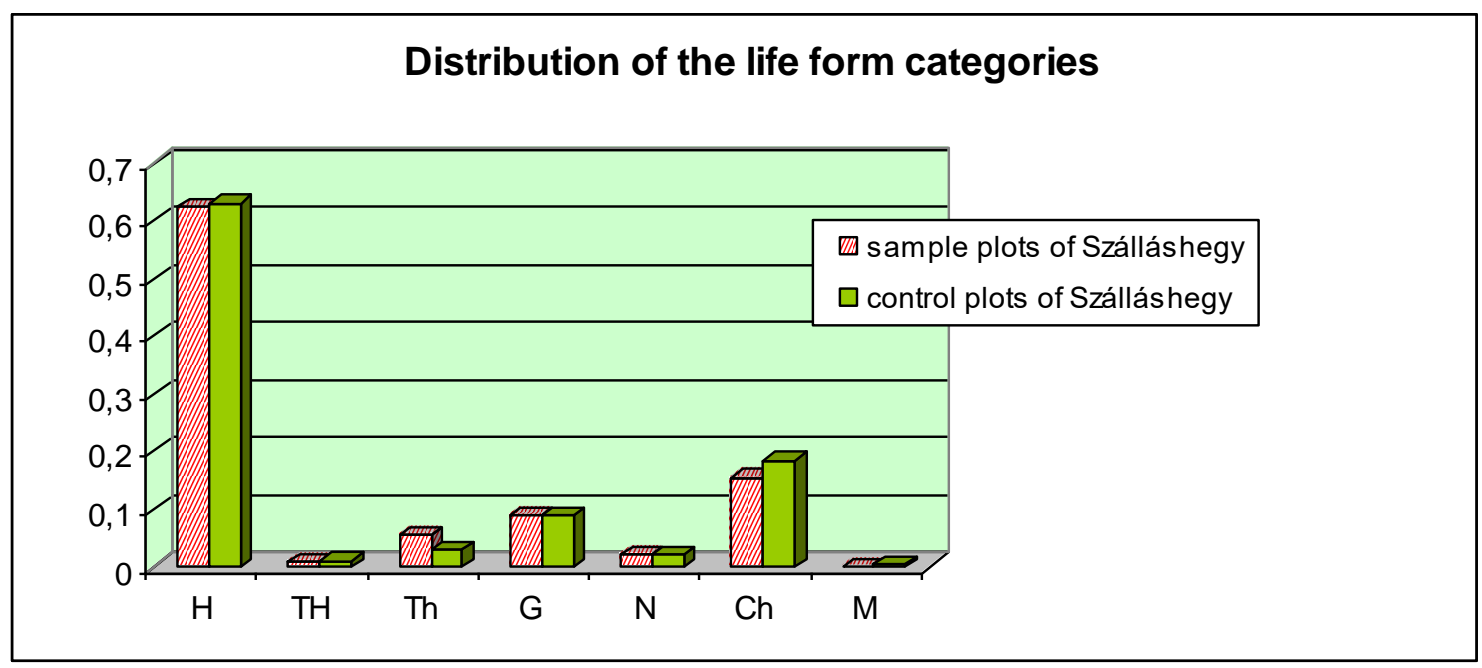

Figure 6. Distribution of the life form categories of the sample and control plots of Szállás-hegy

The distribution of social behaviour types shows that the ratio of generalists is significant higher in the sample plots than in the control plots (Fig. 7).

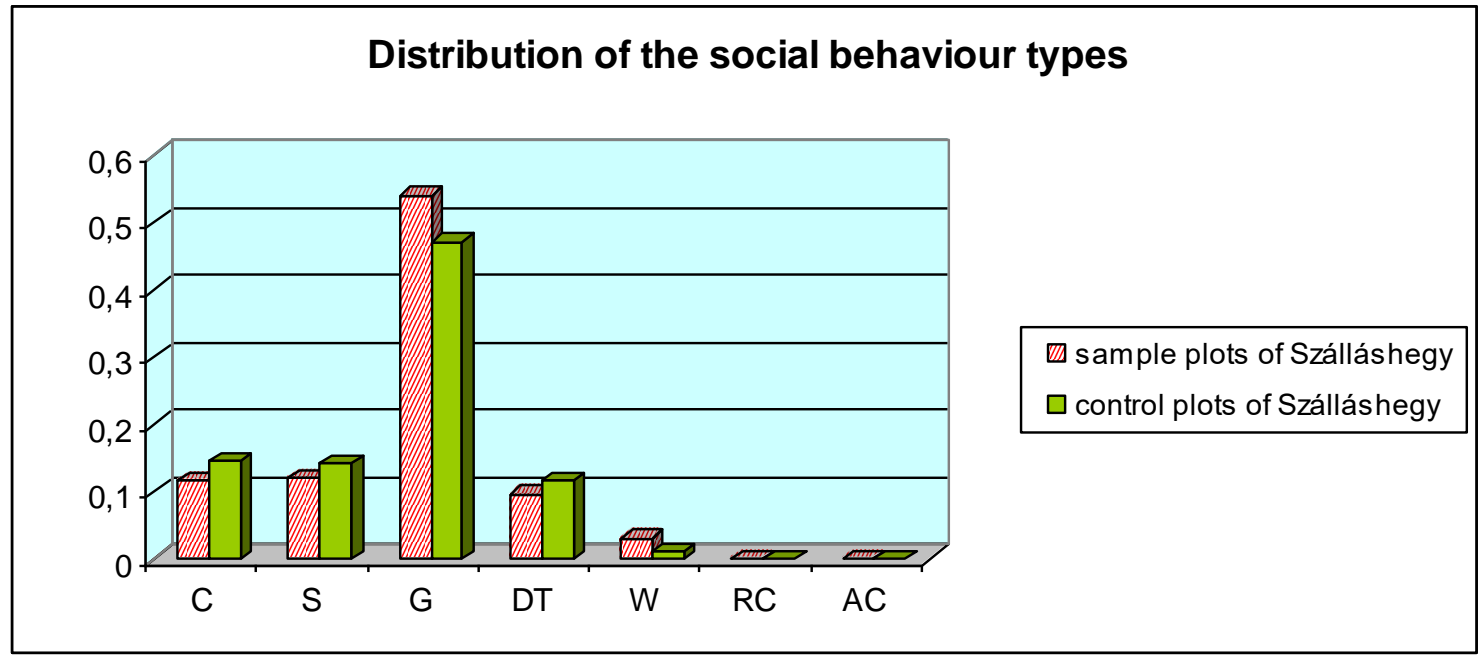

Figure 7. Distribution of the social behaviour types of the sample and control plots of Szálláshegy

On the ordination diagram (Fig. 8) the most dividing variables are the proportion of leaf litter, uncovered soil surface, Carex humilis and Festuca rupicola. Beside of C3 and $\mathrm{C} 4$ plots, the disturbed and control plots are divided from each other. 


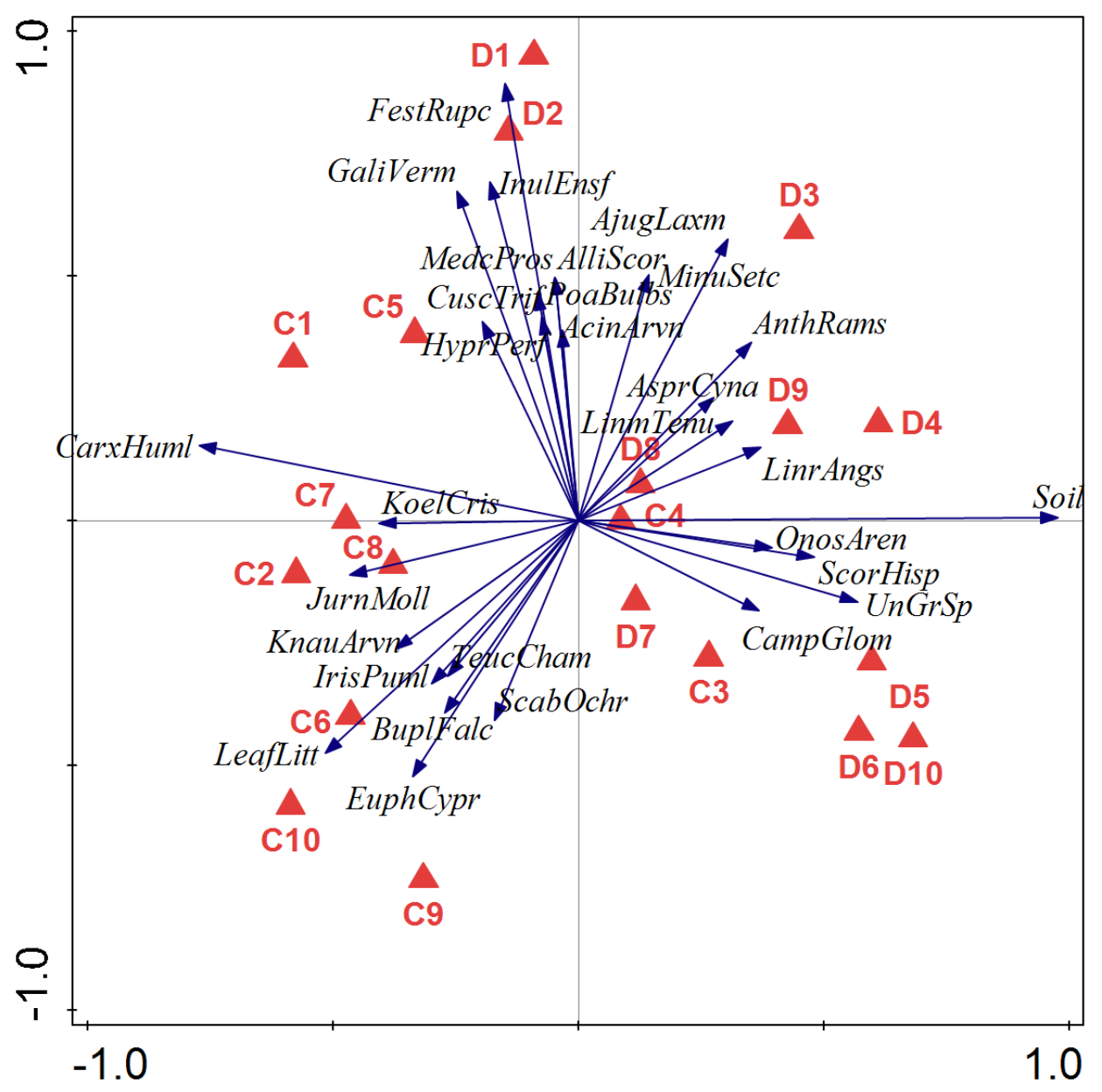

Figure 8. RDA ordination diagram of the plots of Szállás-hegy (D-disturbed, C-control)

An unexpected additional data according to Szállás-hegy site is that we found a new locality of the rare endemic species Vincetoxicum pannonicum. This rare species was first described by Borhidi and Priszter (1966) in the Csiki-mountains. According to the literature this species was found in the following places of Csiki-mountains: Ló-hegy, Futó-hegy, Szekrényes-hegy, Sorrento, Farkas-hegy, Odvas-hegy and in Fekete-hegyek. There is one known locality beside of the Buda Mountains in the Villányi Mountains (Harsány-hegy) (Priszter and Borhidi, 1967; Somlyay and Pifkó, 2002). According to the valid red list of IUCN, there are 4 known localities of Vincetoxicum pannonicum in the Buda Mountains in the present (Király, 2013). Therefore, our data means a new locality of the species. To find out more about the distribution of the species we searched the nearby hills and found two more new localities which did not have references yet. The three new localities are the following ones: Szállás-hegy, Út-hegy and Kö-hegy. The estimated number of individuals was different between the localities. On the Szállás-hegy there were approximately 150-200, on the eastern side of Út-hegy there were 75-100 and on the Kö-hegy there were 50-100 individuals. In several places we found plants which appeared to be different from Vincetoxicum hirundinaria and Vincetoxicum pannonicum. After we submitted our manuscript in 2013, later an article was published on the internet by Sramkó Gábor mentioning these localities too (http1). 


\section{Kutya-hegy site}

Close to Nagykovácsi (Buda Protected Landscape Area) the fixed samples were set on Kutya-hegy evidently near the tourist path. This region is a frequented resort used by hikers, horse riders and bikers. We observed several tourist groups leaving the paths and walking on the protected area, collecting flowers, including protected species, e.g. leopard's bane (Doronicum hungaricum). The control plots were set near to the tourist track in an undisturbed part of the area. On the dendrogram (Fig. 9) at value of $\mathrm{D}=35$ we have 4 groups but the second group consists only one plot (2). The third group consists two smaller groups which are mixed from sample plots $(8,9,10)$ and control plots $(18,20,19,11,12)$. The first and fourth group contains only trod or control plots. In the plots of the first group the similarity is caused by presence of Veronica verna, high cover value of Potentilla arenaria and the low cover value of Carex humilis. The 2nd plot extremely differ from the 1st group because of the high cover value of Fragaria vesca, Thymus glabrescens, low cover value of Sanguisorba minor and lack of Galium verum and Helianthemum ovatum. In the third group there are mixed plots from sample plots $(8,9,10)$ and some control plots $(18,19,20)$. The following species are the same in these plots: Euphorbia cyparissias, Galium verum and Iris pumila, but they differ in presence or absence of Achillea pannonica, Allium flavum, Asperula cynanchica, Botriochloa ischaemum, Cytisus nigricans, Filipendula vulgaris, Fragaria vesca, Helianthemum ovatum, Koeleria cristata, Medicago minima, Salvia pratensis, Sanguisorba minor and Thlaspi perfoliatum. The 11, 12 plots are separated from others with high cover values of Arabis hirsuta, Thlaspi perfoliatum and Viola tricolor and lack of Galium verum. The 13,14, 15 plots are cut from other groups because of higher values of Botriochloa ischaemum. The last group is composed from plots 16 and 17. Its position is caused by the higher rate of Euphorbia cyparissias and Filipendula vulgaris.

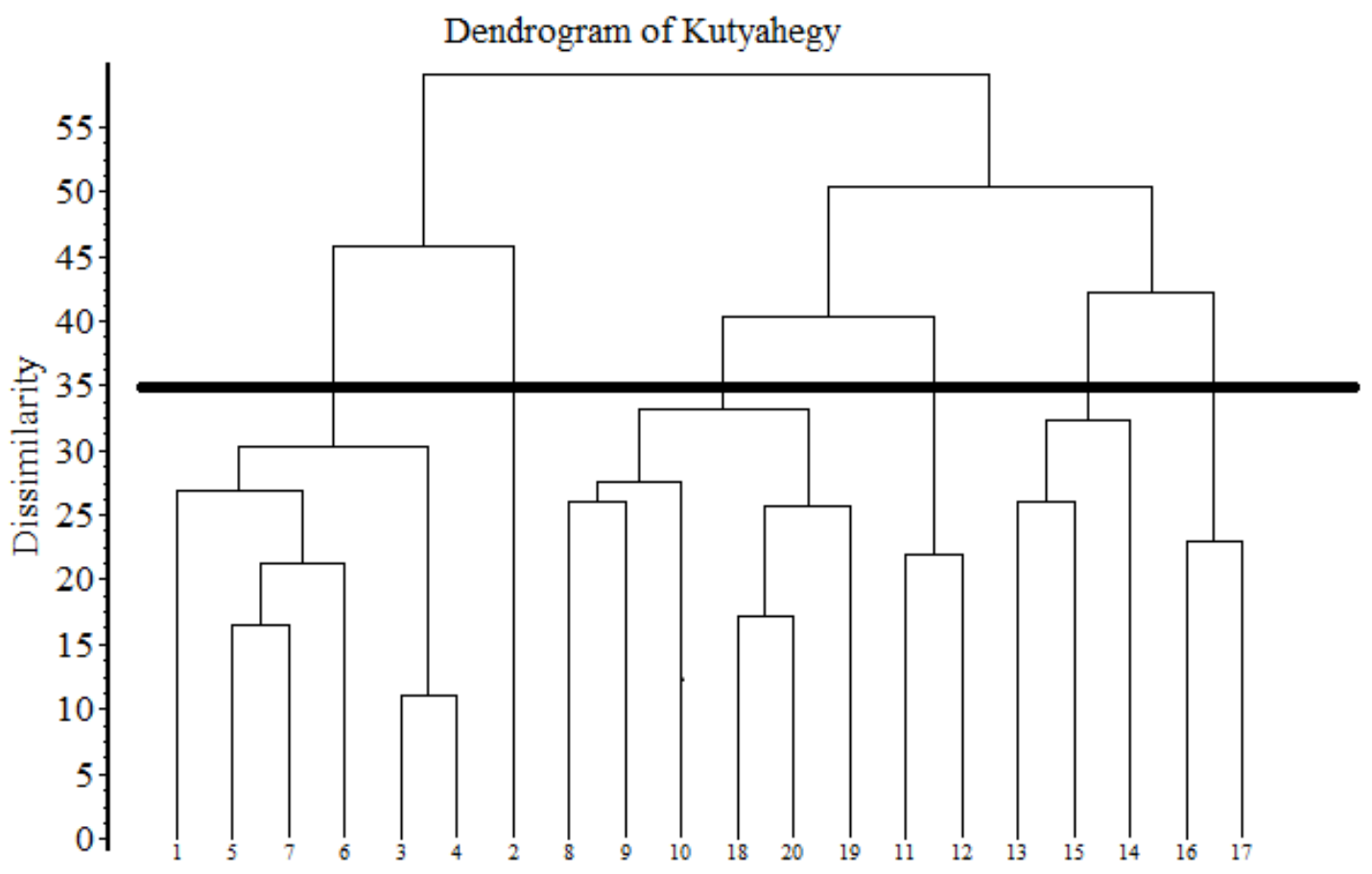

Figure 9. Dendrogram of the sample (1-10) and control (11-20) plots of Kutya-hegy 
The distribution of life form categories does not show any significant difference between the sample plots and the control plots (Fig. 10).

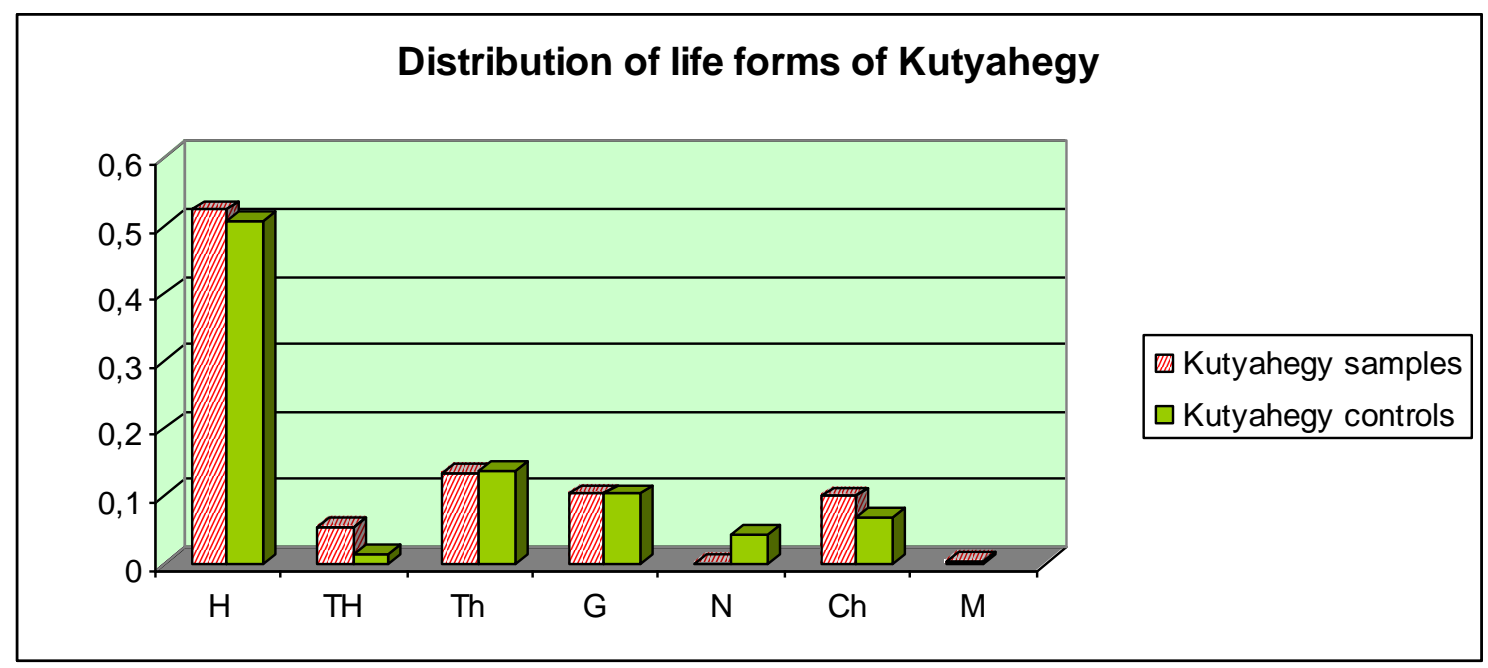

Figure 10. Distribution of the life forms of sample and control plots of Kutya-hegy

With regards to the distribution of plant species based on their social behaviour types, more generalists and fewer specialists can we observe in the sample plots than in the control plots (Fig. 11).

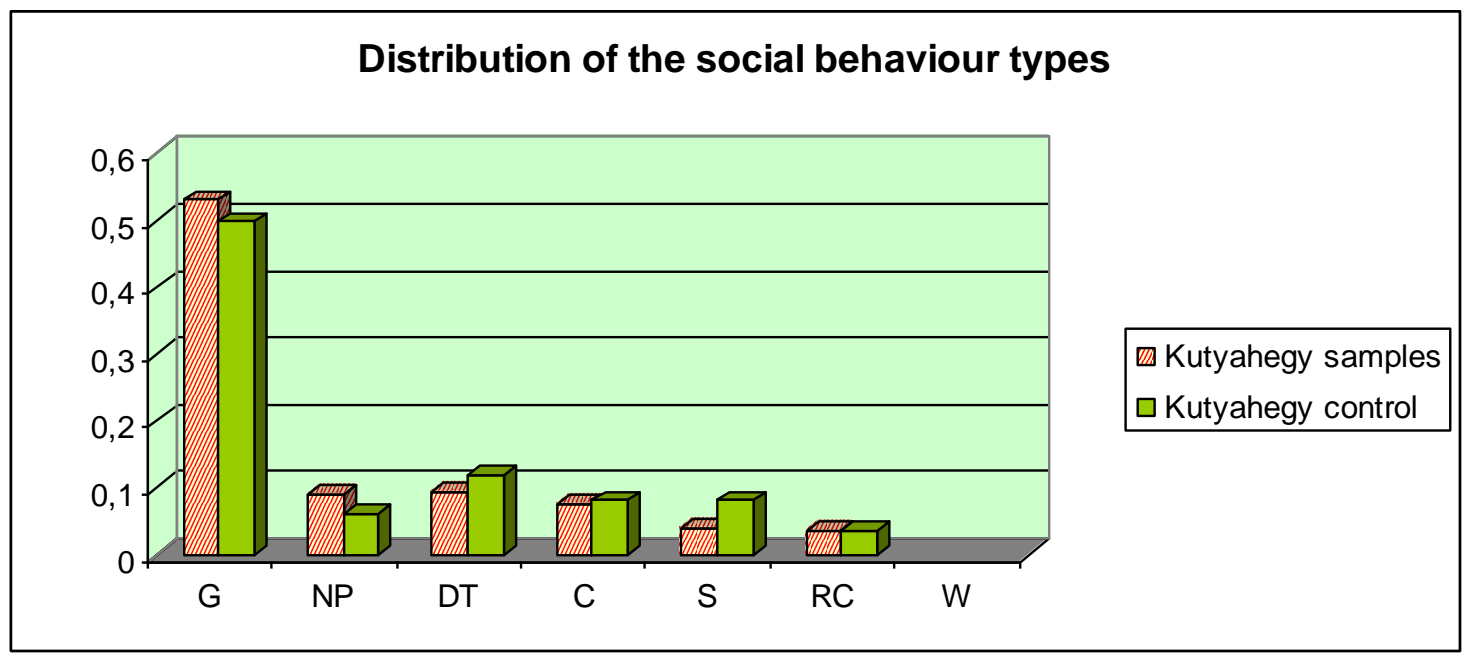

Figure 11. Distribution of the social behaviour types of sample and control plots of Kutya-hegy

On the ordination diagram (Fig. 12) there are 4 separate groups according to the species composition, but the control and the disturbed plots are divided from each other. According to the presence of Carex humilis, Fragaria vesca, Veronica austriaca, Thymus glabrescens and a few more species, some control plots are closer to some disturbed plots than to the other control plots. 


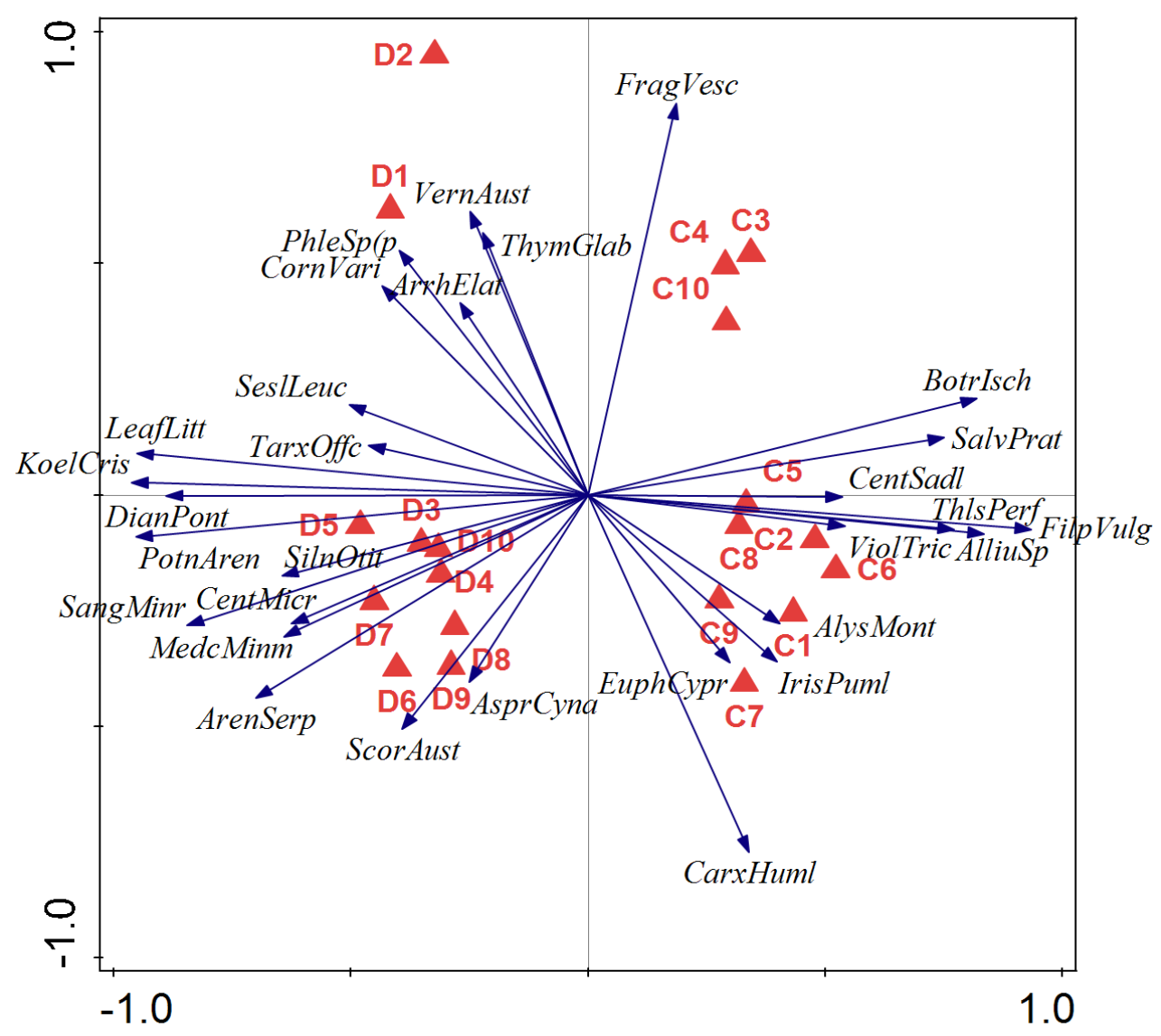

Figure 12. RDA ordination diagram of the plots of Kutya-hegy (D-disturbed, C-control)

\section{The Pilis site}

Pilis is the tallest peak $(756 \mathrm{~m})$ of the Pilis Mountains, so this is a frequented and beloved place for picnic and paragliding although it is part of the Duna-Ipoly National Park. Its plant communities are valuable and some of them are unique in the Carpathian Basin. There are some important localities of many rare plants of Hungary, e. g. Dianthus pontederae, Orchis sambucina, Sesleria sadleriana and the biggest population of Ferula sadleriana, which is a praeglacial relic endemism. The surveyed area of the peak in the last decades was a military post of Russian Army, so partly it was closed for the tourists. After the 90's the area was opened for tourists and paragliders, so this very valuable area of Pilis was impaired by treading acutely. The staff of the National Park Directorate settled a fence to defend this area from the grazing of mouflons. Some years later the grass layer of the peak of the Pilis changed to a "grass ocean" and the stand of Ferula sadleriana unfortunately decreased. Later the fence around the Ferula stand disappeared and probably now a new balance evolved. In these years a smaller part of the protected area is fenced because of paragliding. In the last years the paragliders destroyed the fence several times, removed the last barrier which could stop their illegal sport activities. Without the fence, this site is frequently visited despite the strict prohibition. The paragliders cut out shrubs and woods to "clear" their take off place, other visitors use to cut and collect wood to set up campfire in the middle of the highly protected area. The paragliding activity is actually the most serious risk to the local 
Ferula sadleriana population, by treading and pulling their equipments on grasslands the paragliders break the fragile stems of these plants. Our sample plots were taken at the tourist path also used by paragliders to jump off the peak. The control plots were placed $1.5 \mathrm{~m}$ in parallel from the sample plots. This year there were so many individuals of Ferula sadleriana, its stand may be firmed.

The dendrogram (Fig. 13) shows that the trod plots (1-10) stand apart from control (11-20) plots. The species composition of plots 1, 2, 4 and 10 has high rate of Festuca rupicola and a low rate of the soil surface that differ from the other trod quadrates. In the control plots the plot 11 strictly differs from the others because of the presence of Orlaya grandiflora and Plantago argentea and the higher rate of Achillea pannonica and Thymus pannonicus. In the plots 19 and 20 the higher cover value of Geranium sanguineum and a lower cover value of Festuca rupicola differs from the other control plots. The next species founder present only in the sample plots: Artemisia absinthium, Berteroa incana, Bromus erectus, Bromus mollis, Capsella bursa-pastoris, Poa compressa, Poa pratensis, Poa trivialis, Polygonum aviculare, Silene vulgaris, Sisymbrium altissimum, Tanacetum corymbosum, Verbascum lychnitis, Veronica triphyllos and Viola arvensis. Campanula glomerata, Asperula cynanchica, Hypericum perforatum, Festuca valesiaca, Lolium perenne, Lotus borbasii, Medicago prostrata, Potentilla recta, Sanguisorba minor, Trifolium campestre, Scabiosa ochroleuca, Scorzonera hispanica, Silene conica, Tanacetum corymbosum and Verbascum lychnitis only occur in control plots. In the sample plots the rate of uncovered soil surface is meaningful and the stony surface and the leaf litter cover are higher than in control plots. The specimens of Ferula sadleriana were found both in sample and control plots, but in the control plots the plants were higher and fertile. In the sample plots the Ferula plants were mainly short $(5 \mathrm{~cm})$ and dried.

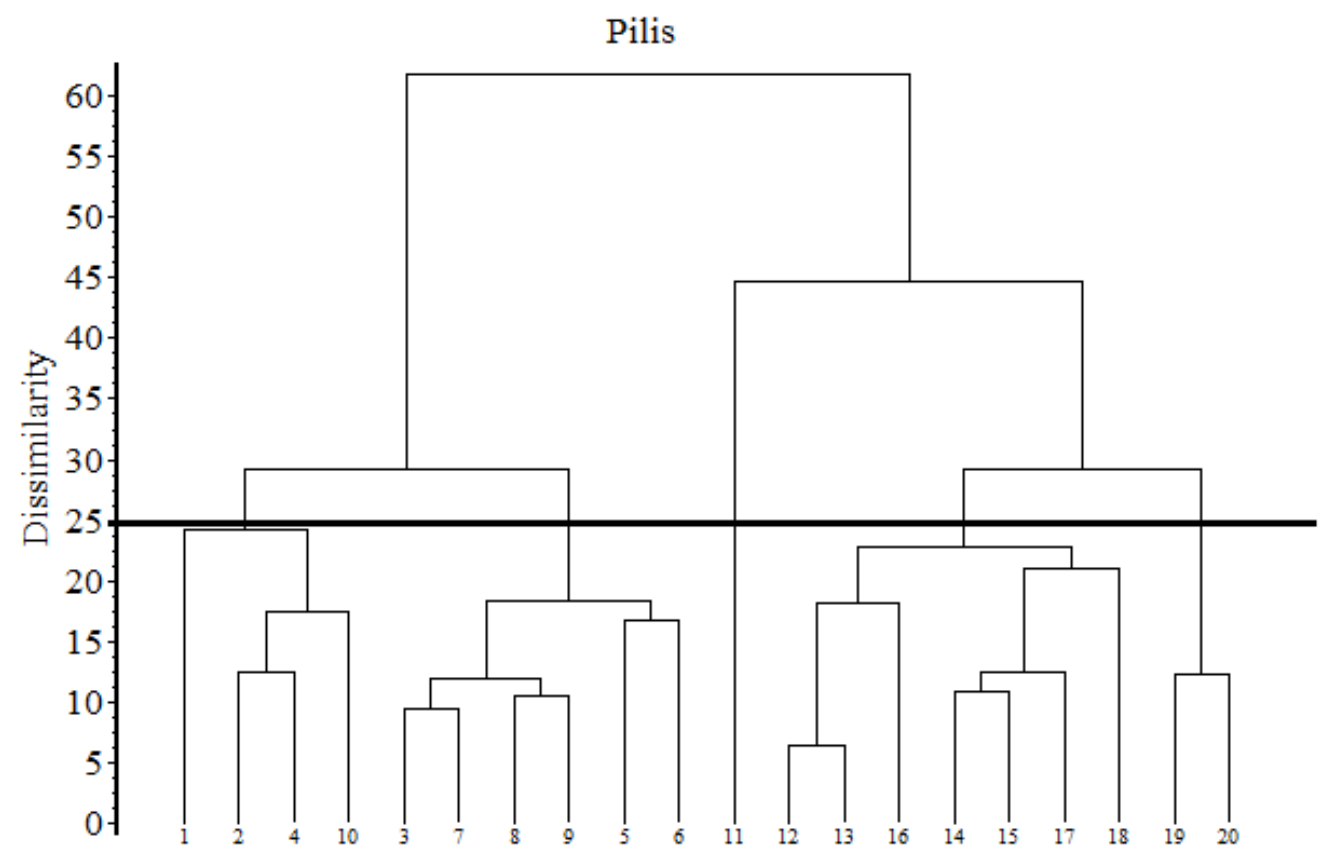

Figure 13. Dendrogram of sample (1-10) and control (11-20) plots of Pilis 
The distribution of life form categories shows significant difference in the category of hemikryptophytes and therophytes between the sample plots and the control plots. The ratio of hemikryptophytes in the sample plots is lower than in the control plots, besides, the ratio of therophytes is higher there than in the control plots (Fig. 14).

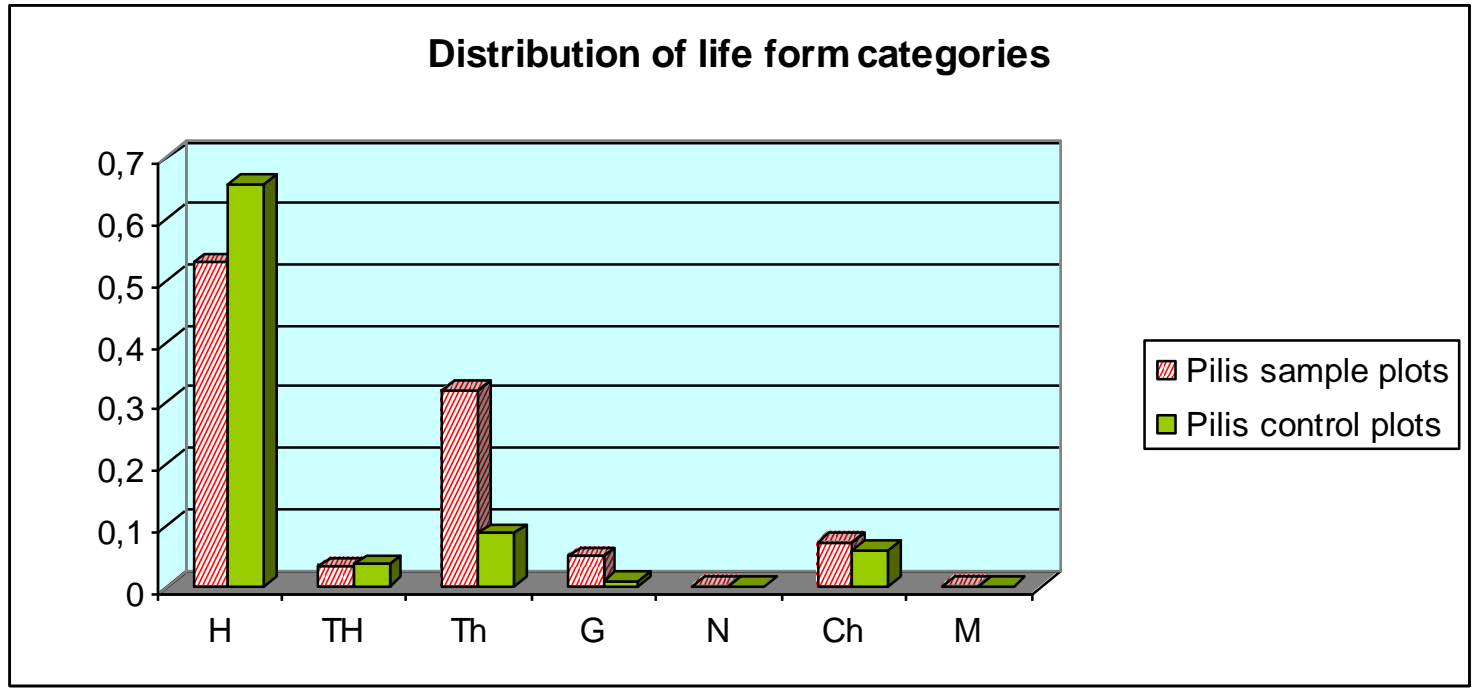

Figure 14. Distribution of the life form categories of the sample and control plots of Pilis

The distribution of social behaviour types shows that the ratio of stress tolerators, ruderal competitors and weeds is significant higher in the sample plots than in the control plots. There are fewer generalists, specialists and competitors in the sample plots than in the control plots (Fig. 15).

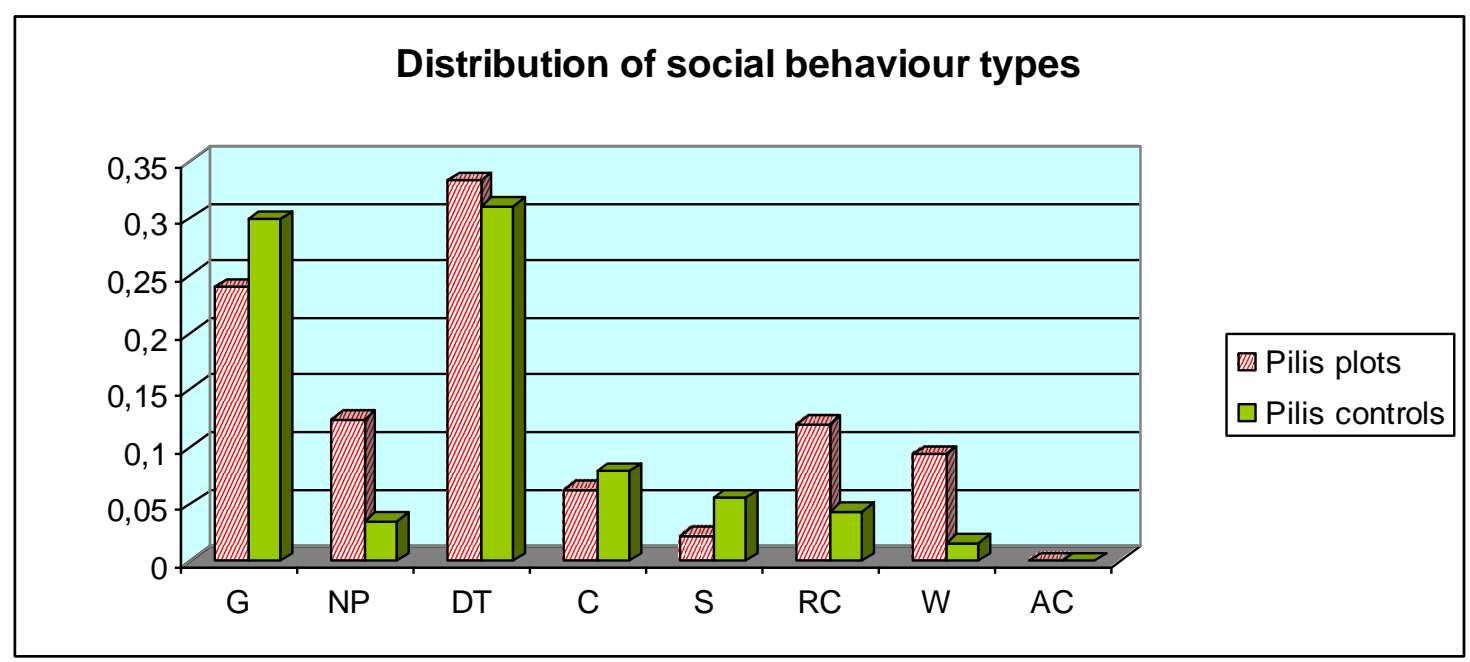

Figure 15. Distribution of the social behaviour types of the sample and control plots of Pilis

On the ordination diagram (Fig. 16) the disturbed and the control plots are divided from each other clearly, forming two uniform groups. Only the $\mathrm{C} 1$ plot differs with its species composition from the other control plots. The two groups of plots differ from 
each other mainly in the proportion of Phleum phleoides, Elymus repens, uncovered soil surface and Veronica triphyllos.

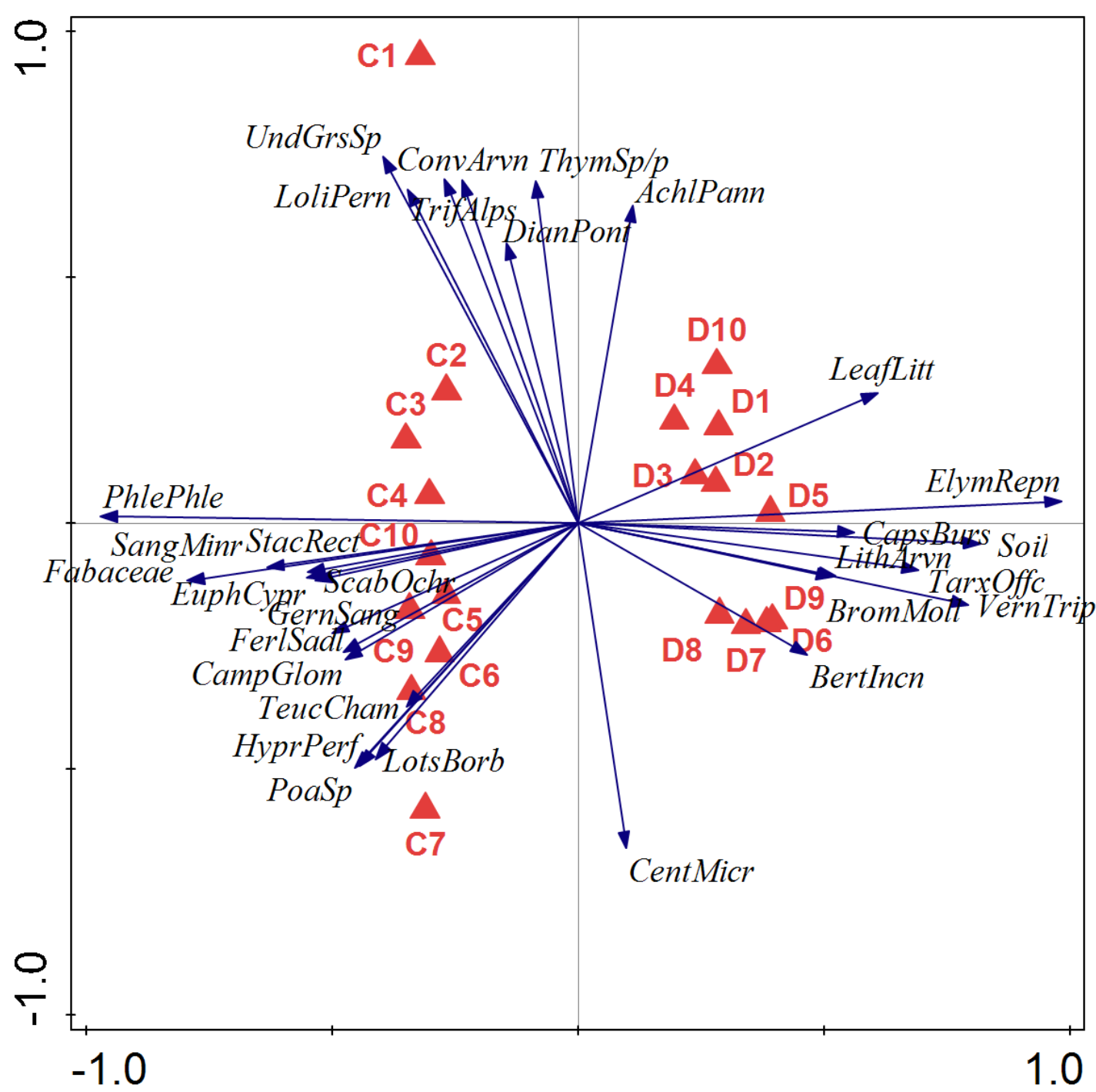

Figure 16. RDA ordination diagram of the plots of Pilis (D-disturbed, $C$-control)

\section{Conclusions}

The distribution of social behaviour categories (Fig. 3, 7, 11, 15) normally shows higher ratio in the categories of generalists, ruderal competitors and weeds in the sample plots while the ratio in the categories of natural competitors and specialists decreases there. Thus, the number of species having higher naturalness value declines due to human influences. It was also found in urban habitats that species of natural grasslands were more typical in peri-urban habitats compared to the city centres characterised by higher human impacts (Deák et al., 2016). The life forms categories (Fig. 2, 6, 10, 14) normally shows higher ratio in the categories of therophytes and chamaephytes in the sample plots than in the control plots. Results of our sites shows complete distribution of trod and control plots of Pilis. In the sample plots the rate of uncovered soil surface 
was meaningful and the stony surface and the leaf litter cover were higher there than in the control plots. In the other sites this kind of distributions is not so clear in the sampling year because of extremely dry weather. These results are probably caused by the extreme dry weather during the summer of 2013 and partly in 2012. In sites of Szállás-hegy, Sas-hegy and Kutya-hegy the dryness was likely a stronger factor that year than the erosive and/or disturbance processes of treading. It was also found in other grassland types, that rainfall fluctuations can cause marked changes in the vegetation composition of dry grasslands (Lukács et al., 2015).

However, we can find similarities between the sample plots at different areas, too. Potentilla argentea besides Festuca rupicola seems to be frequent in the disturbed plots and the cover values of Carex humilis may be lower in these plots.

All of this leads to the conclusion that sport activities by human being can profoundly change the composition of the associations and the nature conservation work is very important in the controlling of weeds and in the preservation of protected plants. We should carry out more effective nature protection in these areas, especially in the very valuable site of Pilis.

Acknowledgements. This work was supported by TAMOP projects (TÁMOP-4.2.1.B-11/2/KMR-20110003, TÁMOP-4.2.2.A-11/1/KONV-2012-0007) and Reserch Center of Excellence- 14764/2016/FEKUT.

\section{REFERENCES}

[1] Albert, Á.-J., Kelemen, A., Valkó, O., Miglécz, T., Csecserits, A., Rédei, T., Deák, B., Tóthmérész, B., Török, P. (2014): Trait-based analysis of spontaneous grassland recovery in sandy old-fields. - Applied Vegetation Science 17: 214-224.

[2] Bánhidi, M. (2012): Leisure és rekreáció - szaknyelvi értelmezés a külföldi szakirodalom tükrében. [Interpretation of leisure and recreation of professional terminology in foreign reports] Magyar Sporttudományi Társaság [Hungarian Scientific Society of Sports] Rekreológia 1: 56-60.

[3] Borhidi, A. (1995): Social behavior types, the naturalness and relative ecological indicator values of the highre plants in the Hungarian Flora. - Acta bot. hung. 39(1-2): 97 181.

[4] Borhidi, A., Priszter, Sz. (1966): Eine neue Cynanchum-art (C. pannonicum n. sp.) in Ungarn. - Acta Botanica Academiae Scientiarum Hungaricae Tomus 12(3-4): 241-254.

[5] Campbell, B. D., Stafford Smith, D. M., Ash, A. J., Fuhrer, J., Gifford, R. M., Hiernaux, P., Howden, S. M., Jones, M. B., Ludwig, J. A., Manderscheid, R., Morgan, J. A., Newton, P. C. D., Nösberger, J., Owensby, C. E., Soussana, J. F., Tuba, Z., ZouZhong, C. (2000): A synthesis of recent global change research on pasture and rangeland production: reduced uncertainties and their management implications. - Agriculture, Ecosystems and Environment 82: 39-55.

[6] Coupland, R. T. (1992): Approach and generalizations. - In: Coupland, R. T. (ed.): Ecosystems of the world. 8 A Natural Grassland, Introduction and Western Hemisphere, 1-6 pp. Elsevier, New York.

[7] Deák, B., Valkó, O., Török, P., Végvári, Zs., Hartel, T., Schmotzer, A., Kapocsi, I., Tóthmérész, B. (2014): Grassland fires in Hungary - experiences of nature conservationists on the effects of fire on biodiversity. - Applied Ecology and Environmental Research 12(1): 267-283.

[8] Deák, B., Hüse, B., Tóthmérész, B.: Grassland vegetation in urban habitats - testing ecological theories. Tuexenia 36: in press. 
[9] Dobay, B., Bánhidi, M. (2009): Sportturizmus kutatásában alkalmazott módszerek [Used methods in research of sport tourism]. - In: XXI.Didmattech 2008 2nd part, Eger Komárno : 2nd part, 259-269 p., Eszterházy Károly College -Eger, J.Selye University Komárno.

[10] Edginton, C., Chen, P. (2009): Leisure and transformation 2008. - Sagamore Publishing, L.L.C. $63-77 \mathrm{p}$.

[11] Fekete, G., Tuba, Z. and Melkó, E. (1988): Background processes at the population level during succession in grasslands on sand - Vegetatio 77: 33-41.

[12] Horváth, F., Dobolyi, Z.K., Morschhauser, T., Lőkös, L., Karas, L., Szerdahelyi, T . (1995): Flóra adatbázis 1.2. Taxon-lista és attributum állomány [Hungarian Flora Database 1.2. Taxon list and attributum stands.] Vácrátót.

[13] Király, G. (2013): Vincetoxicum pannonicum. - In: IUCN 2014. IUCN Red List of Threatened Species. Version 2014.1. <www.iucnredlist.org>. Downloaded on 12 June 2014.

[14] Leber, R. (2012): Sports and recreation centre prater. [Hungarian Scientific Society of Sports] Magyar Sporttudományi Társaság. - Rekreológia 1: 24-35.

[15] Lukács, B.A, Török, P, Kelemen, A., Várbíró, G., Radócz, Sz., Miglécz, T., Tóthmérész, B., Valkó, O. (2015): Rainfall fluctuations and vegetation patterns in alkali grasslands Self-organizing maps in vegetation analysis. - Tuexenia 35: 381-397.

[16] Murphy, P. E. (1985): Tourism. A community approach. - New York: Methuen, 155-165 pp.

[17] Podani, J. (1993): SYN-TAX 5.0: Computer programs for multivariate data analysis in ecology and systematics. - Abstr. Bot. 17: 289-309.

[18] Podani, J. (1994): Multivariate data analysis in ecology and systematics. - SPB Publishing, The Hague.

[19] Priszter, Sz., Borhidi, A. (1967): A mecseki flórajárás (Sopianicum) flórájához I. - Bot. Közlem.54(3): 149-164.

[20] Somlyay, L., Pifkó, D. (2002): A Lathyrus pallescens (Bieb.) C. Koch Magyarországon, és más adatok a Budai-hegység flórájának ismeretéhez. [Lathyrus pallescens (Bieb.) C. Koch in Hungary and other data to the flora of the Buda Mts.]. - Kitaibelia 7: 237-245.

[21] Šmilauer, P., Lepš, J. (2014): Multivariate analysis of ecological data using CANOCO 5, second edition. - Cambridge University Press, New York.

[22] Tóth, K., Hüse, B. (2014): Soil seed banks in loess grasslands and their role in grassland recovery. - Applied Ecology and Environmental Research 12: 537-547.

[23] Turco, D. M., Riley, R., Swart, K. (2002): Sport Tourism. - Morgantown USA.

[24] Valkó, O., Török, P., Deák, B., Tóthmérész, B. (2014): Prospects and limitations of prescribed burning as a management tool in European grasslands. - Basic and Applied Ecology 15: 26-33.

[25] Zólyomi, B. (1958): Budapest és környékének természetes növénytakarója. [Natural vegetation of Budapest and its surroundings]. - In: Pécsi, M. (ed) Budapest természeti képe. [Natural view of Budapest], Akadémiai kiadó, Budapest.

[26] Zólyomi, B., Fekete, G. (1994): The Pannonian loess steppe: Differentation in space and time. - Abst. Bot. 18: 29-41.

\section{SOURCES FROM THE INTERNET}

[27] (http1) http://termeszetvedelmikezeles.hu/adatlap-novenyek?showAll=0andid=1185, downloaded in 2015. 4. 16. 